\title{
Static measurements of the resilience of Caribbean coral populations
}

\author{
Andrew W. Bruckner \\ Khaled bin Sultan Living Oceans Foundation, 8181 Professional Place, Landover, MD 20785 USA; \\ Bruckner@livingoceansfoundation.org
}

Received 18-VII-2011. C Corrected 12-XII-2011. Accepted 20-XII-2011.

\begin{abstract}
The progressive downward shift in dominance of key reef building corals, coupled with dramatic increases in macroalgae and other nuisance species, fields of unstable coral rubble, loss of structural relief, and declines of major functional groups of fishes is a common occurrence throughout the Caribbean today. The incorporation of resilience principles into management is a proposed strategy to reverse this trend and ensure proper functioning of coral reefs under predicted scenarios of climate change, yet ecosystem processes and functions that underlie reef resilience are not fully understood. Rapid assessments using the Atlantic and Gulf Rapid Reef Assessment (AGRRA) and the IUCN Resilience Assessment protocol can provide baseline information on reef resilience. A key aspect of these surveys focuses on coral population dynamics, including measures of coral cover, size, partial and whole-colony mortality, condition, and recruitment. One challenge is that these represent static measures involving a single assessment. Without following individual corals over time, it is difficult to determine rates of survival and growth of recruits and adult colonies, and differentiation of juveniles from small remnants of older colonies may not be possible, especially when macroalgal cover is high. To address this limitation, corals assessed in Bonaire in July 2010 were subdivided into two categories: 1) colonies on the reef substrate; and 2) colonies colonizing dead corals and exposed skeletal surfaces of living corals. Coral populations in Bonaire exhibited many features indicative of high resilience, including high coral cover (often 30-50\%), high levels of recruitment, and a large number of corals that settled on dead corals and survived to larger size-classes. Overall, the skeletal surfaces of 12 species of corals were colonized by 16 species of corals, with up to 12 settlers on each colony, most (67\%) on M. annularis (complex) skeletons. Nevertheless, completely dead $M$. annularis colonies were common, survivors were frequently reduced in size and subdivided into smaller tissue remnants, and these species exhibited higher amounts of partial mortality than all other species. A notable absence of sexual recruits and juveniles of $M$. annularis illustrates a progressive shift away from a Montastraea dominated system. This shift, characterized by an increasing dominance of smaller, short-lived species such as Agaricia and Porites and a reduction in size of longer-lived massive corals, is occurring throughout the Caribbean. Monitoring of the survival of recruits is necessary to determine whether Caribbean reefs will retain the same function, structure, identity and feedbacks (key signs of resilience) if the losses of M. annularis (complex) continue at present levels. The rapid assessment protocol utilized here allows characterization of colony size structure, partial mortality, recruitment, and whether small corals represent surviving recruits that increased in size or larger (older) colonies that continue to shrink in size. This approach can help determine the history of a site and its resilience. Rev. Biol. Trop. 60 (Suppl. 1): 39-57. Epub 2012 March 01.
\end{abstract}

Key words: resilience, coral size structure, coral recruitment, survival and growth, coral monitoring and assessment.

Until the late 1970s, benthic substrates on Caribbean reefs were occupied primarily by reef-building corals, with 50-80\% benthic cover by living corals. Coral reefs exhibited a generalized zonation pattern with elkhorn coral (Acropora palmata) forming large, monospecific stands in the reef crest and shallow fore reef (0-5 m depth); stands of staghorn coral (A. cervicornis) at intermediate depths $(5-25 \mathrm{~m}$ depth) on wave exposed reefs and in shallow, protected environments; massive corals (dominated by Montastraea annularis complex) 
throughout the fore reef (5-30 m depth) and in back reef and lagoonal areas; and plating agaricids near the base of the reef (20-40 m depth) (Goreau 1959). Coral cover has plummeted on Caribbean reefs primarily due to the near total demise of branching acroporids during the 1990s (Aronson \& Precht 2001, Aronson et al. 2002, Bruckner 2003, Gardner et al. 2003), which is now being followed by massive losses of Montastraea annularis (complex) (Bruckner \& Bruckner 2003, 2006a,b, Edmunds \& Elahi 2007, Bruckner \& Hill 2009).

Changes to Caribbean reefs, attributed largely to coral diseases, hurricanes, mass mortality of the herbivorous long-spined sea urchin (Diadema antillarum), localized human impacts, recent bleaching events and climate change (Lessio 1988, Carpenter 1990, Sutherland 2004, Weil 2004,Grimsdith \& Salm 2006) have manifested as dramatic phase shifts characterized by a dominance of macroalgae and other nuisance species, fields of unstable coral rubble, loss of three-dimensional structure, and increases in abundance of shorter-lived brooding corals such as Agaricia and Porites (Hughes 1994, Edmunds \& Carpenter 2001). Many of these stressors have cumulative negative impacts on coral reef ecosystem health and are integrally linked. For example, the virulence and severity of diseases is elevated during and immediately following bleaching events and other periods of elevated environmental stress (Bruno et al. 2007, Ballantine et al. 2008, Muller et al. 2008, Rogers et al. 2008, Bruckner \& Hill 2009). Other human impacts such as overfishing of groupers, snappers, parrotfish, lobster and other species can have cascading impacts on ecosystem health by removing keystone species that are critical in controlling harmful algae, corallivores and other pests (Jackson et al. 2001, Mumby 2006, Green \& Bellwood 2009). These "pest" species compromise remaining corals through direct competition and overgrowth, and may prevent recruitment of coral larvae and regrowth of damaged corals.

Although many of the threats affecting coral reefs have been examined in detail since the early 1990s, very few studies have identified a single direct cause of these impacts (a "smoking gun"), or site-specific remedies or treatments for particular problems. Conversely, there has been a proliferation of publications and reports presenting broad scale recommendations on the need to address destructive human activities such as pollution and overfishing, and the benefits associated with the establishment of marine protected areas (Folke et al. 1996, Roberts 1997, Roberts et al. 2001, Hughes et al. 2003, 2005, Almany et al 2007, 2009, Jones et al. 2009,.. There is good evidence that reduced fishing pressure, and in particular the protection of herbivorous fish populations, can prevent trophic cascades and coral-algal phase shifts (Mumby 2006, Mumby et al. 2006). Furthermore, restoration of certain keystone invertebrates, such as Diadema antillarum, and increases in density of large herbivorous fishes can trigger a reversal from a macroalgal dominated state and promote coral recruitment (Edmunds \& Carpenter 2001, Carpenter \& Edmunds 2006, Hughes et al. 2009, Norstrom et al. 2009). As climate change poses a growing threat to the persistence of these ecosystems, it is imperative that these efforts are scaled up, as degradation is outpacing the potential for recovery in absence of management interventions.

Over the last decade, research efforts have placed a greater emphasis on examining coral reef health and resilience, with a goal to identify strategies to enhance the resilience of these ecosystems (Hughes et al. 2003, 2005). Ecological Resilience is a term which describes the capacity of a system to absorb, resist or recover from disturbance, or to adapt to change, while continuing to maintain essential functions, structure, identity and feedbacks (Hollings 1973, Nystrom \& Folke 2001, Nystrom et al. 2008, Obura \& Grimsditch 2009). There is considerable evidence that sites with chronic human impacts are the least likely to resist mortality and subsequently recover from acute large-scale events, but by addressing these human impacts, they may be better able to cope with acute events such as climate change and 
recover from both natural and anthropogenic impacts (Jennings \& Kaiser 1998, Worm et al. 2006, Knowlton \& Jackson 2008). MPAs, when properly designed and enforced may help promote resilience to disturbances by increasing or maintaining key ecosystem parameters such as fish biomass and coral cover, and help maintain critical ecosystem processes and functions (Cote et al. 2001, Halpern 2003). However, in some cases MPAs may not produce tangible conservation benefits, and they are often not accepted by resource users (McClanahan et al. 2006), emphasizing the need for alternate management strategies. While great strides have been made in understanding interrelationships among corals, fishes, and algae and the role of certain functional groups in enhancing the health of coral reef ecosystems, large gaps remain in our understanding of the dynamic and complex processes that promote or undermine resilience (Hughes et al. 2005).

A detailed assessment of resilience relates to the entire scope of positive and negative factors affecting the ecosystem. This includes ecological, environmental and physical factors as well as social factors such as patterns of resource uses and extraction, type and extent of pollution, presence of invasive species, governance structures, economics, and effectiveness of existing conservation and management efforts (Hughes et al. 2005). Quantitative ecological indicators of resilience, that can be measured include: 1) functional group abundance, species diversity and community redundancy, with emphasis on corals, algae, large motile invertebrates and fish communities; 2) the ecological interactions that drive dynamics within and among these groups; 3 ) habitat and environmental influences that directly affect reef associated organisms and interactions between them; and 4) external drivers of change, including anthropogenic and climate factors, and the level of connectivity with other reefs, (Cowen et al. 2006, Lindsey \& Bruno 2008, Nystrom et al. 2008, Green \& Bellwood 2009, Obura \& Grimsditch 2009).

The Atlantic and Gulf Rapid Reef Assessment (AGRRA) and the IUCN Resilience
Assessment protocols (Obura \& Grimsdith 2009, Lang et al. 2010) are two different rapid ecological assessment approaches that can provide an indication of the ecological resilience of a coral reef. Both of these share common attributes, and they highlight the importance of the inclusion of ecologically relevant fishes, algal functional group biomass/cover, and coral population structure in rapid assessments. The IUCN protocol includes other measures as well, such as a qualitative assessment of various ecological and biological factors as well as physical factors that promote resilience through shading, screening, cooling and enhanced stress tolerance (Obura \& Grimsditch 2009). A detailed resilience assessment also includes characterization of reef processes, such as complex food-web interactions (e.g. herbivory, trophic cascades) reproductive cycles, population connectivity, and coral and fish recruitment, as well as examination of biological characteristics (e.g. genetics of corals and zooxanthellae, symbiont performance, and coral species susceptibility to bleaching, diseases and other stressors).

Because comprehensive measurements of resilience, incorporating the parameters described above and others, are not possible using a single rapid assessment, this study focused solely on one aspect of resilience, coral population dynamics. The approach represents a hybrid between the AGGRA and IUCN protocols, with a few modifications. Detailed measures of colony size (length, width and height) were taken for each coral, along with an estimate of the extent of partial colony mortality. This prevents a potential underestimation of the original colony size that would occur if only the live portion is considered when classifying coral size. The number and diversity of recruits and juveniles (colonies $<4 \mathrm{~cm}$ diameter) are also recorded. Recruitment is often considered an indicator of resilience (i.e. signs of recovery following chronic or acute disturbances) (Mumby \& Harborne 2010). However, without following recruits over time it is difficult to determine survival rates of these recruits, or whether they are contributing to population 
recovery. Survival of recruits, and growth to larger size-classes was assessed by distinguishing between colonies on the reef substrate and those found on exposed skeletal surfaces of other corals; the latter represents both recruits and surviving juveniles. This method was tested in July 2010 in Bonaire, and the results of these assessments are presented here.

\section{MATERIALS AND METHODS}

Study site: In July 2011, the Living Ocean Foundation conducted rapid assessments on 24 sites off the leeward side of Bonaire and the adjacent Klein Bonaire, targeting Montastraea dominated reefs from 5-15 m depth. All of these sites are fringing reefs that begin close shore and drop to deeper water within a few hundred meters. Many of the areas above $5 \mathrm{~m}$ depth were badly damaged by recent hurricanes and are largely devoid of corals, but much of the Montastraea structure at mid depths is still intact. The sites were grouped into 3 distinct areas: a) sites north of Kralendijk located off a rocky coastline; b) sites off the small offshore Klein Bonaire; and c) sites south of Kralendijk located off a sand and low relief limestone shoreline, many of which have a double reef system (Fig. 1, Table 1).

Assessment protocol: The resilience assessments conducted in Bonaire include measures of corals, fish, algae and motile invertebrates through application of attributes of the Atlantic and Gulf Rapid Reef Assessment (AGRRA) protocol, the IUCN bleaching resilience protocol, and several additions. Data were collected using a combination of belt transects, point intercept methods and photographic documentation. While numerous biological, ecological, physical and social measures must be analyzed concurrently to gain a full picture of coral reef resilience, this manuscript focuses specifically on one aspect of resilience (coral population resilience) evaluated through a static measure of coral population dynamics. Seven parameters were recorded for corals: 1) benthic cover; 2) coral diversity and abundance

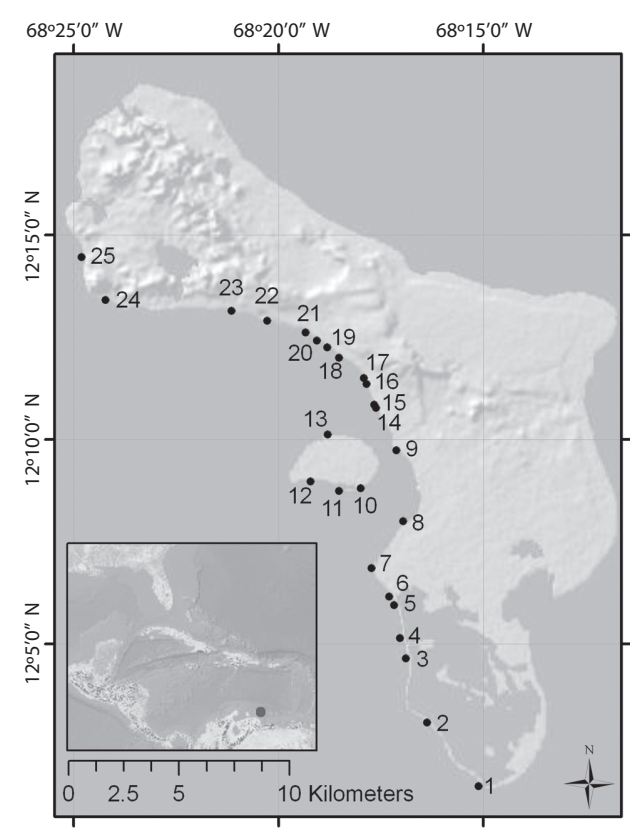

Fig. 1. Locations of reef assessments in Bonaire. Sites are listed from south to north. Numbers correspond to the site names listed in Table 1.

(by species); 3) coral size class distributions (by species) and size of tissue remnants; 4) amount of partial mortality and number of tissue remnants; 5) recruitment; 6) location of settlement of recruits; and 7) coral condition. Belt transects, each $10 \mathrm{~m}$ long and $1 \mathrm{~m}$ wide (minimum of three per reef), were extended parallel to depth gradients on each reef. Within this belt, each coral $4 \mathrm{~cm}$ or larger in diameter was identified to species, measured and assessed for condition. A one meter bar, marked in $1 \mathrm{~cm}$ increments was used to measure the maximum diameter, width (perpendicular to the diameter), height, and amount of mortality. Mortality was divided into three categories: recent, transitional and old.

Benthic cover: Cover of substrate and benthic organisms (algae and invertebrates) was estimated using a point intercept method. At each site, a minimum of six 10 meter long transects were deployed. The organism and 
TABLE 1

Location of sites examined in Bonaire

\begin{tabular}{|c|c|c|c|}
\hline Site \# & Reef Name & Longitude W & Latitude N \\
\hline 1 & Red Slave & -68.251800 & 12.025550 \\
\hline 2 & Margate Bay & -68.272867 & 12.051350 \\
\hline 3 & The Invisibles & -68.281383 & 12.077617 \\
\hline 4 & Jeannie's Glory & -68.283833 & 12.085733 \\
\hline 5 & Alice in Wonderland & -68.286217 & 12.099233 \\
\hline 6 & Angel City & -68.288267 & 12.102750 \\
\hline 7 & Lighthouse Point & -68.295417 & 12.114350 \\
\hline 8 & Windsock & -68.282583 & 12.133317 \\
\hline 9 & Something Special & -68.285250 & 12.162250 \\
\hline 10 & Keep Sake & -68.299760 & 12.146800 \\
\hline 11 & Monte's Divi & -68.308710 & 12.145660 \\
\hline 12 & South Bay & -68.320133 & 12.149650 \\
\hline 13 & Knife & -68.313250 & 12.168610 \\
\hline 14 & Small Wall & -68.293483 & 12.179567 \\
\hline 15 & Black Durgon Reef & -68.294338 & 12.180745 \\
\hline 16 & Andrea I & -68.297483 & 12.189217 \\
\hline 17 & Andrea II & -68.298600 & 12.191600 \\
\hline 18 & Oil Slick Leap & -68.308633 & 12.199950 \\
\hline 19 & Jeff Davis Memorial & -68.313417 & 12.204133 \\
\hline 20 & Weber's Joy/Witches Hut & -68.317617 & 12.206900 \\
\hline 21 & 1,000 Steps & -68.322317 & 12.210183 \\
\hline 22 & Tolo/Ol' Blue & -68.337900 & 12.214883 \\
\hline 23 & Karpata & -68.352383 & 12.218967 \\
\hline 24 & Tailor Made & -68.403630 & 12.223380 \\
\hline 25 & Nukove & -68.413333 & 12.240933 \\
\hline
\end{tabular}

substrate type was recorded every ten $\mathrm{cm}$ for a total of 100 points per transect. Substrates were identified as pavement, rubble, sand/silt, dead coral and live coral. All corals were identified to species. Other invertebrates were subdivided into phylum or class and growth form or identified to genus/species when possible. Algae were divided into five functional groups (fleshy macroalgae, erect coralline algae, crustose coralline algae, turf algae, cyanobacteria) with certain nuisance species recorded to genus (e.g. Microdictyon, Lobophora, Dictyota, Stypopodium, Peyssonnelia). Key invertebrates that also may become nuisance species recorded to genus or higher taxonomic level included: tunicate (Trididemnum), encrusting gorgonian (Erythropodium, Briareum), colonial anemone (Palythoa), encrusting or bioeroding sponge (Cliona langaelaprica complex, Cliona delitrix, Anthosigmella), and hydrozoan coral (Millepora).

Recruitment: Sampling for corals smaller than $4 \mathrm{~cm}$ was done using a minimum of five $0.25 \mathrm{~m}^{2}$ quadrats per transect. Each quadrat located at fixed, predetermined intervals (e.g. 2, $4,6,8,10 \mathrm{~m}$ ), alternating between right and left side of the transect. Recruits were identified in both point intercept surveys and belt transects. These corals were divided into recruits $(0-2 \mathrm{~cm}$ diameter) and juveniles $(2.1-3.9 \mathrm{~cm})$.

\section{Corals colonizing skeletons of other} corals: All corals settling on skeletal surfaces of other colonies (completely dead corals and corals with partial mortality) within each belt 
transect were identified and recorded separately from those corals occurring on reef substrates. For each of these colonies, measurements were taken of the size (length, width and height for colonies $4 \mathrm{~cm}$ or larger; maximum diameter for corals that were $0-3.9 \mathrm{~cm}$ ), and an estimate of percent mortality made for those exhibiting partial mortality.

Condition of corals: Visual estimates of tissue loss, using a $1 \mathrm{~m}$ bar marked in $1 \mathrm{~cm}$ increments, was recorded for each colony over $4 \mathrm{~cm}$ in diameter. If the coral exhibits recent tissue loss, the amount of remaining tissue, the percent that recently died and the percent that died long ago were estimated for the entire colony surface. Tissue loss was categorized as recent mortality (occurring within the last 1-5 days), transitional mortality (filamentous green algae and diatom colonization, 6-30 days) and old mortality ( $>30$ days). For each coral with partial or whole colony mortality, the cause of mortality was identified if possible. The diagnosis included an assessment of the type of disease, the extent of bleaching, predation, competition, or overgrowth, or other cause of mortality. Each coral was first carefully examined to identify cryptic predators such as snails (Coralliophila abbreviata) and fireworms (Hermodice carunculata). Lesions were then diagnosed into four categories: recent tissue loss, skeletal damage, color change, and unusual growth patterns (an individual colony could have multiple characteristics such as color change and recent tissue loss) and when possible a field name was assigned. Diseases were identified according to Bruckner 2010b and Raymundo et al. 2008, and included yellow band disease (YBD), white plague (WP), black band disease (BBD), red band disease (RBD), Caribbean ciliate infection (CCI), dark spots disease (DSD) and white band disease (WBD).

\section{RESULTS}

Coral cover: On most of the reefs examined in this study, between 5-15 m depth, coral cover was high ( 40-60\%;Fig. 2a). The only exceptions were two sites on northern reefs, Webers Joy/Witches Hut and Jeff Davis Memorial $($ cover $=30-35 \%)$, and in certain locations with outbreaks of white plague. Montastraea annularis (complex) were the dominant corals, in terms of living cover, occupying approximately $20-25 \%$ of the benthos, and making up over $50 \%$ of the total live coral cover. The next most common species, in terms of living cover, where Agaricia, Madracis and Porites spp (Fig. 2b). Cover of major functional groups of reef building corals showed slight variations between sites and depths. For instance, cover of M. annularis complex was lowest on northern reefs (pooled for all depths; $22 \%$ vs 24\%) while cover of Agaricia spp. was lowest on southern reefs (6.6\% vs 9\%). Klein Bonaire also had a higher cover by Madracis mirabilis ( $>6 \%$ ); this coral formed large thickets on several reefs that occasionaly extended the length of $10 \mathrm{~m}$ transects or more. There were also differences in coral cover between depths. For instance, Agaricia spp. and Eusmilia fastigiata had the highest cover on all reefs at $15 \mathrm{~m}$. In contrast,cover of Porites was higher at $10 \mathrm{~m}$ and $15 \mathrm{~m}$ depth than at $5 \mathrm{~m}$. Madracis spp. was most variable, having the highest cover at $5 \mathrm{~m}$ depth on northern and southern reefs, and 10 $\mathrm{m}$ depth on Klein Bonaire. Acropora palmata and A. cervicornis were virtually absent from all point intercept surveys, and only identified infrequently in belt transects. Cover of macroalgae was relatively low on all reefs, but was significantly higher on northern reefs (Fig. 2a). There was no correlation between coral cover and macroalgal cover $\left(\mathrm{r}^{2}=0.01, \mathrm{p}=0.56\right)$. Cover of turf algae ranged from $7-38 \%$, and was significantly correlated to coral cover $\left(\mathrm{r}^{2}=\right.$ $0.44, \mathrm{p}=0.0003$ ).

Coral composition: A total of 5957 corals, $4 \mathrm{~cm}$ or larger in diameter, were identified within belt transects $(10 \mathrm{~m} \mathrm{X} 1 \mathrm{~m})$ on 25 reefs in Bonaire (Fig. 3). M. annularis (complex) was the dominant functional group of corals at all sites overall, in terms of numbers of colonies, making up approximately $27 \%$ of all corals. $M$. annularis complex was numerically 

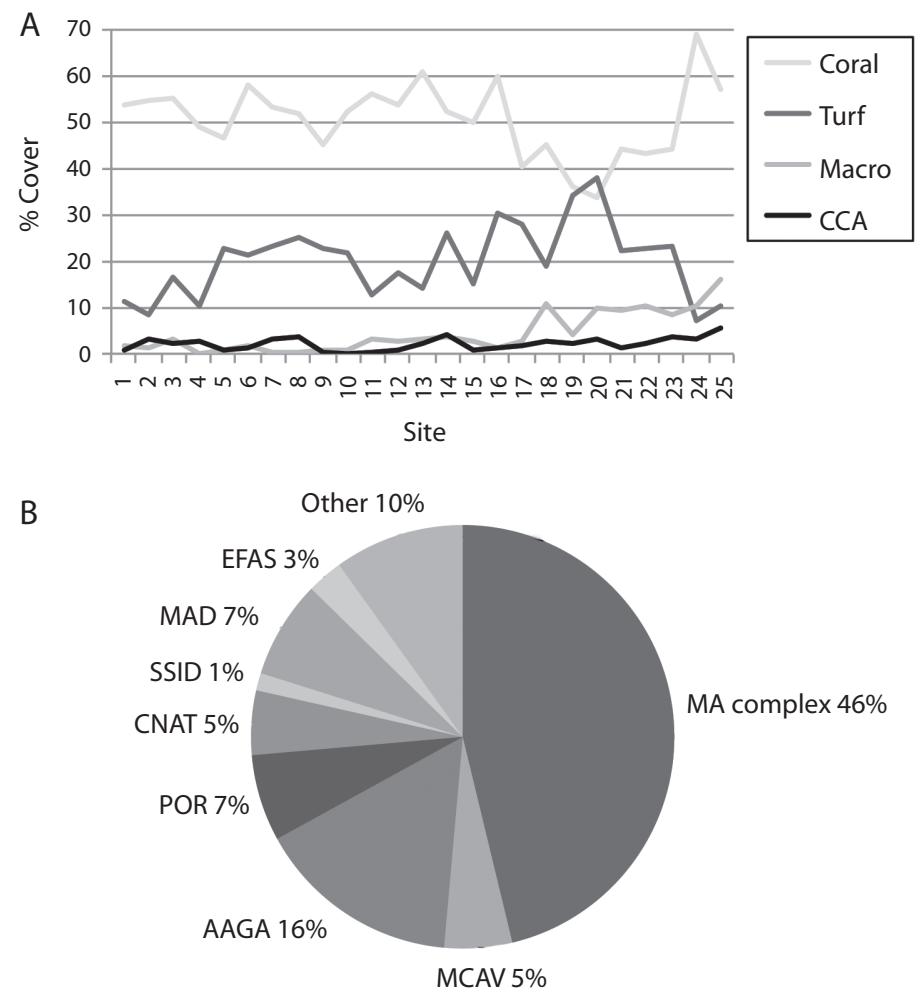

Fig. 2. Benthic cover for 25 reefs examined in Bonaire. A. Mean cover of corals, turf algae, macroalgae, and crustose coralline algae for each reef, from south to north pooled for 5, 10 and15 m depth. B. Cover of each functional group of corals, expressed as a percent of the total living coral cover.

dominant between 5-10 m depth, while Agaricia was slightly more abundant at $15 \mathrm{~m}$ depth. Reefs in the north and off Klein Bonaire had a higher proportion of $M$. annularis (complex) colonies (30 and $29 \%$ respectively), when compared to reefs in the south (21\%). When examined by species, $M$. annularis was significantly more abundant than $M$. faveolata and $M$. franksi on northern reefs and Klein Bonaire, but not southern reefs, while abundance of $M$. faveolata and $M$. franksi was very similar in all locations. The second most abundant functional group was the genus Agaricia (18-26\% of all corals). This genus was the dominant taxon on southern reefs and the second most abundant taxon in other locations. The genus Porites was the third most abundant taxon. While the proportion (number of colonies) of brooding species (especially Agaricia, Porites) was very high, the contribution to living coral cover was less than M. annularis (complex) because these colonies were smaller in size.

Coral size structure: Corals ranged in size from $4 \mathrm{~cm}$ (smallest coral assessed in belt transects; $0-3 \mathrm{~cm}$ corals assessed separately using quadrats and on exposed skeletal surfaces) to over $450 \mathrm{~cm}$ diameter, with a maximum 

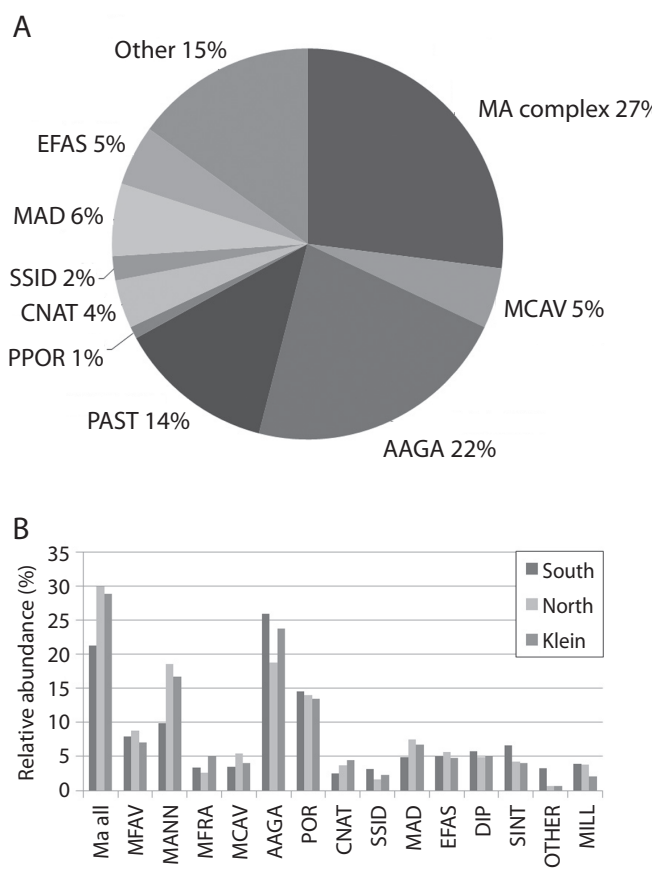

Fig. 3. Coral composition observed in belt transects from 5-15 m depth. A. Composition of corals by functional group pooled for all sites and depths examined in Bonaire. B. The proportion of colonies of each species for northern reefs, southern reefs and Klein Bonaire, pooled for all depths.

height of $460 \mathrm{~cm}$. The size structure of $M$. annularis (complex) shows a bell shaped distribution with few small colonies $(<20 \mathrm{~cm})$ and few very large colonies $(>200 \mathrm{~cm})$ and a large number of medium-sized corals $(30-80 \mathrm{~cm}$ diameter); the population structure also exhibited a second peak for colonies that were 150-199 $\mathrm{cm}$ diameter (Fig. 4a). Colonies of other species (all species except $M$. annularis complex) were dominated by very small colonies $(<20$ $\mathrm{cm}$ ) and populations in all locations (all sites pooled, as well as northern, southern and Klein Bonaire reefs) exhibited a monotonic decline in size with very few colonies over $60 \mathrm{~cm}$ in diameter. Colonies of $M$. annularis (complex) were significantly larger than all other species (mean diameter $=58 \mathrm{~cm}$, versus $24 \mathrm{~cm}$ for other species pooled; original diameter of the colony; Fig. 4b), although large (>1 m diameter) colonies of Siderastrea siderea, Stephanocoenia intersepta, Colpophyllia natans and extensive (2-5 m wide) thickets of Porites porites and Madracis mirabilis were seen.

There was a notable absence of smaller colonies $(<10 \mathrm{~cm})$ of $M$. annularis (complex). It is important to note that these represent measures of the diameter of the entire corallum (the original skeletal surface area) and not the size of tissue remnants on larger skeletal surfaces. Many colonies in the genus Montastraea that had contiguous skeletons,1-3 $\mathrm{m}$ in diameter or larger, were reduced in live tissue area, and individual corals often consisted of multiple tissue remnants (mean $=6.6$ remnants per colony) that were reduced to a few $\mathrm{cm}$ in diameter.

Colony mortality: The amount of partial mortality observed on corals located within belt transects varied from 0-99\%, with significant differences between species, colony sizes and locations (Fig. 5). For M. annularis complex $(n=1602)$, a total of $73(4.5 \%)$ had completely died, with surviving colonies $(n=1529)$ missing a mean of $28 \%$ of their tissue. Tissue loss for these species consisted of $25 \%$ old mortality and $3 \%$ transitional and recent mortality. When examined by size, colonies of $M$. annularis (complex) with less than $30 \%$ partial tissue loss were significantly smaller in size (mean diameter $=48 \mathrm{~cm}$; mean tissue loss $=11 \%$; $\mathrm{n}=889$ ) than colonies with $30-99 \%$ partial tissue loss (mean diameter $=61 \mathrm{~cm}$; mean tissue loss= $50 \%$; $\mathrm{n}=639$ ). However, a correlation analysis using the entire range of sizes (no pooling into size classes) showed that tissue loss was not significantly correlated with colony size. This may be due to the fact that colonies exhibited a high range of tissue loss in all size classes: each size class contained colonies with no mortality, moderate levels of mortality and extensive mortality. Individual colonies of $M$. annularis (complex) were also frequently divided into a number of smaller patches of live tissue; on average, each coral was subdivided into 6.6 separate tissue remnants. 


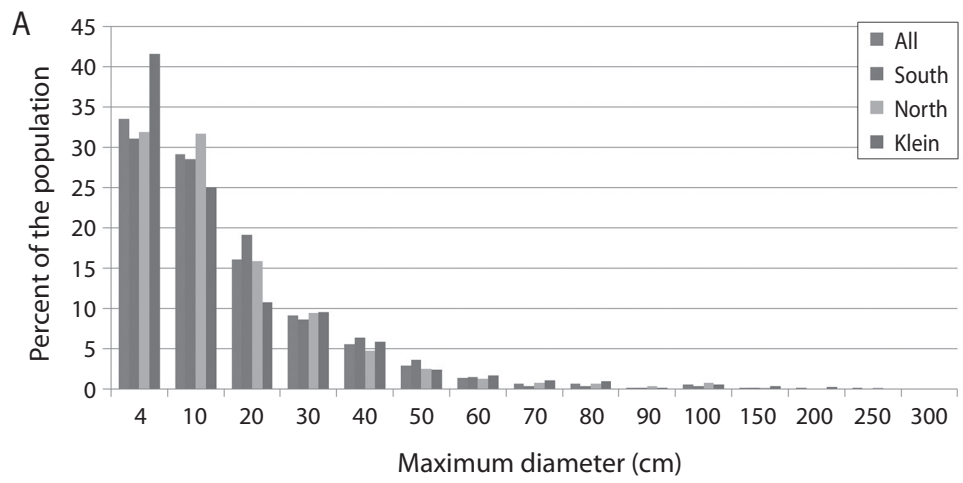

B

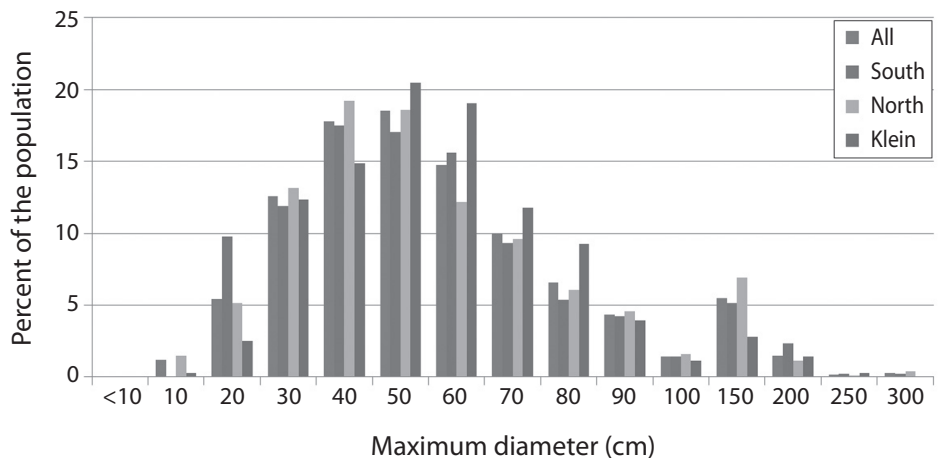

Fig. 4. Population demographics of reef-building corals on 25 reefs examined in Bonaire. A. Size structure of all species except for M. annularis complex. B. Size structure of $M$. annularis complex. Blue bars= all reefs; red bars= southern reefs; green bars= northern reefs; purple bars= Klein Bonaire.

Tissue loss for other corals (all species except $M$. annularis complex) was significantly lower (mean partial tissue loss $=8 \%$ ) and fewer dead colonies were identified $(n=20,0.4 \%)$. Interestingly, partial mortality for colonies that had colonized reef substrates was higher than partial mortality for colonies that had colonized exposed skeletal surfaces of living corals $(9.4 \%$ vs $7.6 \%)$. These corals were also less frequently subdivided into smaller tissue remnants (mean=1.41 remnants/colony), possibly because they were younger and smaller in size overall.

Based on size structure, abundance, levels of recruitment, and coral condition, coral communities could be divided into two primary groups, the $M$. annularis complex (M. annularis, M. faveolata and M. franksi) and all other species. Corals lumped into "other species" were small to medium-sized (mean $=24 \mathrm{~cm}$ ), and population structure exhibited a monotonic decline in size; most colonies were $<20 \mathrm{~cm}$ in diameter and very few colonies were over 60 $\mathrm{cm}$. Although a small proportion of colonies showed active signs of disease and competition from other biotic stressors, these corals had low levels of partial mortality (8\%), few completely dead colonies were observed $(0.4 \%)$, and they were the predominant species colonizing dead skeletal surfaces of other corals as well as reef substrates.

Recruits on reef substrate: A total of 1688 quadrats, each $0.25 \mathrm{~m}^{2}$, were examined on 25 reefs in Bonaire. Over $40 \%$ of the quadrats contained at least one coral $(0-3 \mathrm{~cm}$ in 

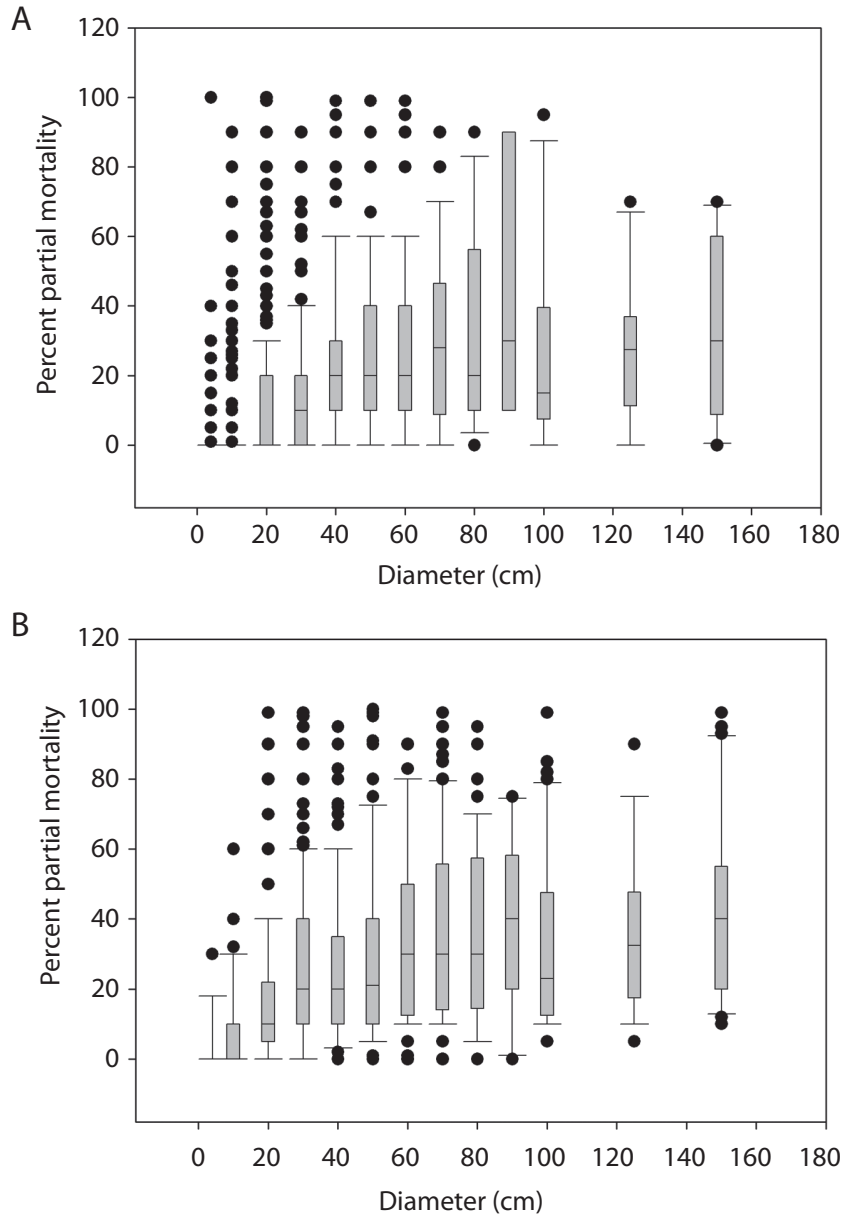

Fig. 5. Relationship between partial mortality and colony size for A. M. annularis (complex), and B. All other species (pooled) shown as a box plot. The boundary of the box illustrates the $25^{\text {th }}$ and $75^{\text {th }}$ percentile, the line within the box marks the median, error bars indicate the $10^{\text {th }}$ and $90^{\text {th }}$ percentile, and outlying points are shown as black dots. Colonies are pooled into 13 size classes, 4-9 cm, 10-19 cm, 20-29 cm, 30-39 cm, 40-49 cm, 50-59 cm, 60-69 cm, 70-79 cm, 80-89 cm, 90-99 $\mathrm{cm}, 100-124 \mathrm{~cm}, 125-150 \mathrm{~cm}$ and $>150 \mathrm{~cm}$.

diameter, classified here as a recruit). A higher proportion of quadrats on southern reefs contained recruits $(45 \%$ vs. $40 \%$ and $37 \%$ of quadrats on northern reefs and Klein Bonaire, respectively). Individual quadrats contained a maximum of 5 recruits (northern and southern reefs) and 8 recruits (Klein Bonaire) each. Eighteen different species of scleractinian corals and two hydrozoan corals were observed in quadrats. There was a notable absence of sexual recruits of $M$. annularis, $M$. faveolata and $M$. franksi, although numerous tissue remnants $<4 \mathrm{~cm}$ in diameter were noted. The dominant corals observed as recruits included A. agaricites $\left(\right.$ mean $=3.9$ recruits $\left./ \mathrm{m}^{2}\right), P$. astreoides $($ mean $=2.2$ recruits $\left./ \mathrm{m}^{2}\right)$, and Madracis spp (mean = 0.95 recruits $/ \mathrm{m}^{2}$ ) while all other species were at densities of $<0.2 / \mathrm{m}^{2}$ (Fig. 6a). Species that were common as adults within transects, but not observed in quadrats included Mussa angulosa, Mycetophyllia lamarckiana, M. aliciae, Dendrogyra cylindricus, Isophyllia sinuosa, I. 
A

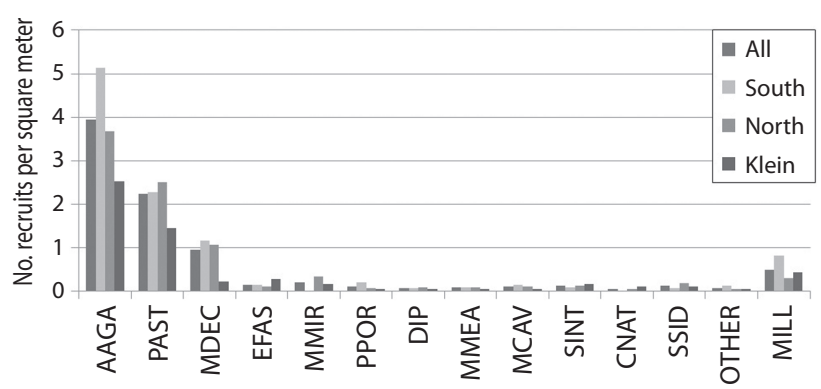

B

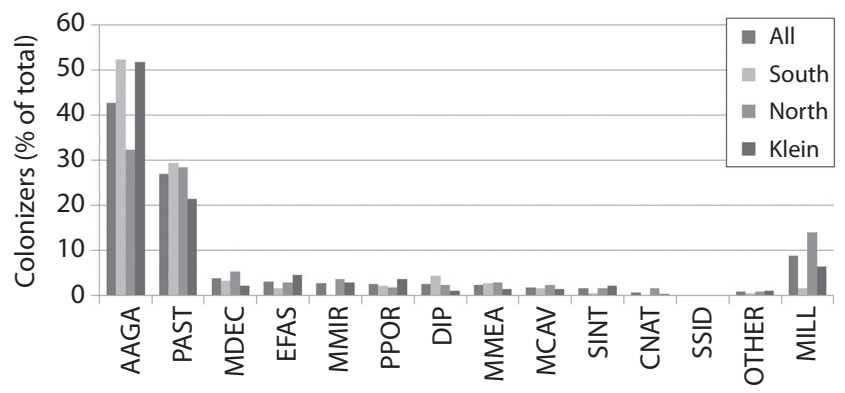

Fig. 6. A comparison between recruits settling on reef substrate (A) and recruits settling on dead coral skeletons (B).

rigida, S. intersepta, Scolymia spp., Acropora palmata, and A. cervicornis.

Colonization of coral skeletal surfaces: The exposed skeletal surfaces of 249 corals were colonized by new stony corals. Corals that supported these settlers were missing a mean of $60 \%$ of their tissue. Difference in partial mortality occurred between regions, with colonies from southern reefs that were colonized by other corals showing much higher amount of partial mortality overall. M. annularis (complex) colonies that supported settlers of other species were similar in size in all three locations, and they were significantly larger than all other species that were colonized by new corals (Table 2).

A total of 12 species of corals supported colonizers (Fig. 7), although most were observed on M. annularis (36\%) and M. faveolata $(35 \%)$. A much higher proportion of $M$.

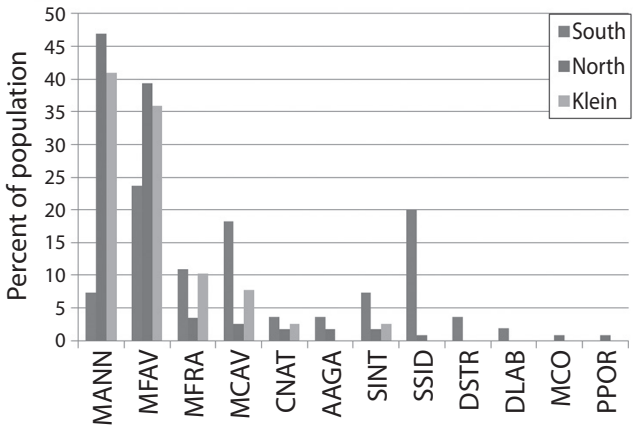

Fig. 7. Species of coral supporting coral settlers on northern, southern and Klein Bonaire reefs.

annularis (complex) skeletons on Klein Bonaire $(19 \%)$ were colonized by corals as compared to northern (13\%) and southern (5.3\%) reefs. Exposed skeletal surfaces of other species were less frequently colonized by new corals, with exception of $M$. cavernosa and S. siderea on 
TABLE 2

Mean size and condition of corals that supported colonization by other species of corals. Corals are pooled into Montastraea annularis complex (Ma), other species (other) and all corals (all), subdivided into northern (N), southern (S) and Klein (K)Bonaire reefs.

\begin{tabular}{lccccccccc} 
& N & $\%$ & \# remnants & Max Diam $(\mathrm{cm})$ & Width $(\mathrm{cm})$ & Max Height $(\mathrm{cm})$ & \% old mortality & \% recent & \% total mortality \\
All & 248 & 4.7 & 4.8 & 66 & 60 & 58 & 58 & 0.8 & 59 \\
Ma (S) & 23 & 5.3 & 3.3 & 70 & 61 & 53 & 71 & 1.7 & 73 \\
Ma (N) & 105 & 12.9 & 5.9 & 74 & 67 & 66 & 60 & 0.9 & 61 \\
Ma (K) & 67 & 19.3 & 5.5 & 65 & 59 & 60 & 51 & 0.7 & 52 \\
Other (S) & 32 & 2.2 & 2.4 & 49 & 44 & 38 & 63 & 0.0 & 63 \\
Other (N) & 12 & 0.8 & 2.2 & 49 & 45 & 40 & 49 & 1.1 & 50 \\
Other (K) & 10 & 1.6 & 2.1 & 51 & 48 & 46 & 52 & 0.0 & 52 \\
\hline
\end{tabular}

southern reefs (Fig. 4). No differences in the number of settlers per unit area were noted between reef substratum and exposed $M$. annularis skeletal patches.

Overall, 825 corals of 16 species were identified as colonizers on these corals, with up to 12 observed on a single colony. These settlers were up to $30 \mathrm{~cm}$ in diameter, with most (49\%) from $4-7 \mathrm{~cm}$ in diameter and $<10 \%$ that were 3 $\mathrm{cm}$ or smaller. Agaricia agaricites $(43 \%)$ and $P$. astreoides (27\%) were the most common colonizers, although broadcast spawners were also observed (Fig. 6b). Interestingly, some species observed as recruits were not observed to settle on dead skeletons ( $S$. siderea). The proportion of colonizers also differed significantly from the proportion of recruits observed on the reef substrate among some species (e.g. fewer $M$. decactis and higher percentage of colonizers of E. fastigiata, C. natans, Diploria spp., $M$. cavernosa, P. Porites, M. meandrites, and $S$. interepta), but not all species (Agaricia and $P$. astreoides). There was also a notable absence of $M$. annularis (complex) recruits and colonizers on dead skeletons. While $M$. annularis (complex) was not observed recruiting onto any exposed skeletal surfaces, juvenile corals $(4 \mathrm{~cm}$ or larger) that had settled on dead coral surfaces represented $17.5 \%$ of all corals of other species (all species except $M$. annularis) identified within belt transects.

\section{DISCUSSION}

Assessment protocols for stony corals frequently rely on single or repeat assessments of coral cover as the primary metric to characterize reef condition and gauge changes. This approach assumes that reefs with high coral cover are in better shape and exhibit higher resilience (Gardner et al. 2003, Bruno \& Selig 2007), yet coral cover may actually be one of the last metrics to indicate ecosystem failure (Bellwood et al. 2004, McClanahan et al. 2011). A second coral metric that has received greater attention in recent years is an assessment of recruitment, whereas high levels of recruitment may suggest a reef is rebounding after a disturbance (Mumby \& Harborne 2010). In addition, studies characterizing impacts, such as coral diseases, usually rely on a count the number of colonies in a given area to provide some indication of prevalence or incidence of the particular condition (Raymundo et al. 2008). These parameters alone may fail to provide a reliable measure of reef resilience because they fail to take into account factors affecting the fitness and dynamics of coral populations. Namely, corals are modular (clonal) organisms can undergo growth, shrinkage, fission into several ramets, and fusion; subunits can function independently and they exhibit indeterminate growth (Babcock 1991). 
Two of the most important parameter to consider when assessing resilience of coral populations is size and amount of partial mortality, as mortality and fecundity rates in corals are strongly size-dependent (Harrison \& Wallace 1990). Smaller corals are generally more vulnerable to stressors, while the likelihood of total colony mortality decreases with increasing colony size (Babcock \& Mundy 1996, Hall \& Hughes 1996). Corals also show a positive relationship between colony size and fecundity, with smaller colonies allocating more energy to non-reproductive life history traits such as growth and maintenance and focusing on reproduction after achieving a critical threshold size (Szmant-Froelich 1985). Reproductively mature colonies may also regress in size below that minimum threshold, becoming non reproductive (Szmant 1991). In addition, competitive abilities and regenerative potential also increases with size (Meesters et al. 1994).

Since colony size can influence patterns of mortality and fecundity, population size frequency distributions provide insight into the effects of disturbance and population processes. Coral populations are normally highly positively skewed, with a dominance by the smallest size classes and an exponential decrease with increasing colony size (Bak \& Meesters 1998, 1999). Larger colonies typically become rarer in a population, but they have a decreased probably of total colony mortality than smaller colonies (Hughes \& Jackson 1985, Soong \& Lang 1992). Furthermore, larger colonies show a lower frequency of partial and whole colony mortality, with mortality decreasing in relation to colony size (Meesters et al. 1994). One consequence of this is that smaller colonies suffer total mortality more frequently than larger colonies, while larger colonies sustain higher levels of partial mortality over multiple disturbances, but have a larger chance of survival (Soong 1993). Thus, size frequency distributions of coral populations provide a sensitive means of discriminating changes in coral communities in response to acute and chronic disturbances, and may help identify differences between populations exposed to differing degree of environmental stressors.

Scleractinian coral populations normally exhibit a positively-skewed (left) size frequency distribution with populations dominated by smaller colonies. On a Caribbean Montastraea reef, a population that has not been exposed to a major disturbance for several decades may progressively exhibit a shift towards the opposite extreme, with a dominance of extremely large colonies (negatively-skewed right). In Bonaire, a northern reef (Taylor Made) with a higher coral cover than all other sites examined in this study was dominated by extremely large colonies of Montastraea faveolata and $M$. annularis, many over $200 \mathrm{~cm}$ in diameter and $5 \mathrm{~m}$ in height. This site had few small corals and colonies exhibited little partial mortality, suggesting an absence of a major acute disturbance for several decades, and minimal chronic impacts from disease or other stressors. This reef appears to be in a stable equilibrium at this time. Nevertheless, this site may be pushed over the tipping point towards a trajectory of coral decline by an acute disturbance (e.g. an outbreak of white plague), as it exhibited low coral diversity, low levels of recruitment ,and few juvenile corals. However, the site may also undergo rapid recovery if other resilience factors are present, such as high rates of herbivory, as recruitment may increase once substratum becomes available.

The demographic structure of a coral population also illustrates the presence of past disturbances, where a population dominated by small size classes may indicate high mortality in intermediate and larger corals (Nystrom et al. 2008). Several reefs at the southern end of Bonaire had high coral cover, but they were dominated by a high diversity of small corals, most of which were $4-20 \mathrm{~cm}$ diameter. These reefs included a high proportion brooding species such as Agaricia and Porites, although various brain corals, flower coral, cactus corals and many other species were present. Most Montastraea colonies were small $(<90 \mathrm{~cm}$ diameter), many dead standing colonies of these species were observed, and colonies were 
frequently subdivided into small tissue remnants. Although high numbers of recruits and juvenile corals were present, no Montastraea colonies below $10 \mathrm{~cm}$ diameter were observed. The declining condition of $M$. annularis is indicative of a past disturbance, as well as chronic tissue loss from disease. While coral cover is rebounding, the progressive replacement of $M$. annularis may be indicative of lowered resilience as the community is becoming dominated by smaller, shorter-lived species that are highly susceptible to future perturbations.

By subdividing mortality into three categories, recent, transitional and old mortality, the cause of tissue loss and the timing of a disturbance event may be discernable(Lang 2003). The presence of high levels of recent mortality suggests that a disturbance has occurred and the event is ongoing. Sites containing corals with extensive transitional mortality and little recent mortality were affected by a disturbance in the recent past, but the event has passed and the system may be at the early stages of recovery. At the opposite extreme, if most colonies have extensive patches of old mortality, and little or no recent mortality, it is apparent thatthe site was impacted at some time in the past, but the source of mortality is gone making it difficult to determine when the mortality occurred, or whether it was an acute event or a chronic disturbance. In Bonaire, extent of partial and whole colony mortality was notably different among reefs, with southern reefs showing low levelsof old mortality and the highest amount of recent and transitional mortality. Recent mortality was attributed to an outbreak of white plague; this disease was also present in other locations, but at a lower prevalence.

The challenge faced when assessing colony size and extent of mortality through a single rapid assessment is that it is impossible to determine the growth of a coral population over time. Because corals are clonal animals, they can progressively increase in size with age, theoretically with indeterminate growth, but they can also shrink in size, without dying (Babcock 1991). Through partial mortality colonies are frequently subdivided into isolated tissue remnants, and the original colony boundaries can become obscured by other organisms, especially on reefs with a high cover of macroalgae or other epibionts. A dominanceof small colonies may represent several successful recruitment events, or the small colonies may be surviving remnants of formerly larger corals. A feasible way to differentiate juvenile corals from older surviving remnants, without having to tag individual colonies and return to the site to look at survival over time, is to separate out coral measurements into two categories: those corals found on the reef substrate, and those that have colonized exposed skeletal surfaces of corals with partial or total mortality. All corals that settled onto exposed skeletal surfaces or dead coral skeletons can be considered recruits and not remnants, which is not the case for colonies occurring on the reef substratum. In contrast, small patches of tissue of the same species, that are similar in morphology and coloration to surrounding tissue are likely to be tissue remnants.

In Bonaire, corals frequently settled on most species of massive and plating corals, although the highest settlement and survival rates appear to be on Montastraea skeletons. Settlers included 16 important reef-building species, with a notable absence of Montastraea annularis (complex). The majority of these corals were completely alive, unlike many of the similar sized corals that occurred on the reef substrate. There were however, no differences noted in the number of recruits recorded on coral skeletons of $M$. annularis, versus the reef platform. While the two substrates are equally attractive to settling larvae, dead skeletal surfaces of Montastraea may be optimal, due to high rates of survival and growth into larger size classes (and absence of partial mortality as observed among the same species on reef substratum). Because the settlement surface (coral skeleton) is raised off the bottom, settlers are less affected by sediment transport and siltation, macroalgal competition, and possibly disease. Nevertheless, one species (Siderastrea siderea) recruited onto the reef, but it did not colonize coral skeleton. The 
proportion of colonizers on skeletons that survived to larger size classes also differed among species, indicating that high recruitment does not necessarily equate to high resilience.

The discrimination of corals settling onto skeletal surfaces of other corals provides a useful metric when using a single rapid assessment to determine levels of recruitment, as well as the potential for longer-term survival and growth. This is not be possible when examining coral population dynamics based solely on colonies on the reef substrate, as large corals that undergo shrinkage and fission may be misinterpreted as juveniles (smaller size classes). One complication with this measure is an absence of information on the age of the coral skeleton necessary to attract settling larvae. Corals did settle on exposed skeletal patches of colonies of $M$. annularis (complex) exhibiting slow, chronic mortality from yellow band disease (e.g. areas that were denuded 30-90 days earlier; Bruckner, unpubl data), suggesting coral skeleton of this species becomes suitable for settlement relatively early. However, for other species only long dead skeletal patches, with an absence of macroalgae and other prominent epibionts, appeared to support coral settlers. Although it is not possible to determine the age of the dead skeleton, it was certainly many months to years, as evidenced by the presence of turf algae, crustose coralline algae, and encrusting invertebrates.

The results presented here provide an indication of the resilience of of coral populations in Bonaire. The presence of high levels of recent recruitment and growth of recruits into larger size classes demonstrates that newly settling corals are surviving and contributing to an increase in the proportion of these taxa. The absence of larger size classes of some coral taxa that colonized exposed skeletal surfaces suggest that certain species are recruiting onto these reefs at levels that exceed survival. In addition, the dominant frame-builder $(M$. annularis complex) on these reefs appears to be highly vulnerable to recent disturbances, as populations of these species are being progressively reduced in abundance and size, and they have not shown substantial levels of recruitment needed to replace colonies that died. As observed in other locations throughout the Caribbean, these reefs are undergoing a transition from a Montastraea-dominated system to a community consisting predominantly of other species. Fortunately for Bonaire, these reefs still have unusually high coral cover, high levels of recruitment and good survival of juvenile corals, and several sites contain a high abundance of large, unblemished colonies of Montastraea annularis (complex), all which are important indicators of resilience.

While single assessments will never provide the kind of data that would result from repeated visits to a site over time, single rapid assessments can provide valuable data on the resilience of coral populations. For corals, these assessments must expand upon traditional measures of coral cover and abundance, by incorporating data on recruitment, size structure, partial and whole colony mortality, and the extent of survival and growth of recruits.

\section{ACKNOWLEDGEMENTS}

The intensive surveys completed In Bonaire between July 19-26, 2010 represent the dedicated efforts of a talented group of scientists and field assistants. I am grateful for the assistance and expertise provided by the team to complete rapid ecological assessments, and extensive time devoted to data entry, with special thanks to Eric Borneman, Robin Bruckner, Kalisi Faanunu, Philip Renaud, Glynnis Roberts, Debbie Santavy and Amanda Williams. Al Catafulmo and the Black Durgon Inn graciously accommodated the research team during this mission. I also thank the Government of Bonaire and the Bonaire Marine Park for assistance with permits and other technical aspects associated with the work. All funding for this work was provided by the Khaled bin Sultan Living Oceans Foundation. Surveys were performed under a research permit \#30001380 granted by the Island Council of the Island Territory of Bonaire. 


\section{RESUMEN}

En la actualidad se está viendo en el Caribe un cambio en la composición de los corales constructores de arrecifes, aumento en la cobertura de macroalgas y otras especies, un aumento en áreas cubiertas por escombros de corales, y una pérdida de relieve. La incorporación de principios de resiliencia en el manejo es una estrategia propuesta para revertir esta tendencia y asegurar la sobrevivencia y el adecuado funcionamiento de los arrecifes de coral bajo escenarios previstos de cambio climático. Sin embargo, todavía quedan grandes vacíos en la comprensión de los factores que promueven la resiliencia. Evaluaciones rápidas realizadas con la metodología AGRRA (Atlantic and Gulf Rapid Reef Assessment) y con el protocolo de Evaluación de Resiliencia para arrecifes coralinos de la IUCN brindan información de línea base sobre la resiliencia de los arrecifes del Caribe. Un aspecto clave de estos estudios se centra en la dinámica de las poblaciones de los corales, incluyendo medidas de cobertura de coral, estructura de tallas, la extensión de la mortalidad parcial y total de toda la comunidad, condición de los corales y reclutamiento. Un reto es que esto representa una medida estática que involucra una única evaluación. Sin seguir las colonias individuales y el reclutamiento en el tiempo, es difícil determinar las tasas de sobrevivencia y crecimiento de los reclutas, y podría no ser posible la diferenciación de los juveniles de los restos pequeños de colonias más viejas, especialmente cuando la cobertura algal es alta. Para abordar esta limitación, los corales monitoreados en Bonaire en julio del 2010 fueron subdivididos en dos categorías: 1) colonias sobre la estructura arrecifal; y 2) colonias creciendo sobre coral muerto o sobre las superficies expuestas del esqueleto de los corales vivos. Los arrecifes en Bonaire exhiben muchas características indicativas de alta resiliencia, incluyendo una alta cobertura de coral (frecuentemente $30-50 \%$ ), altos niveles de reclutamiento, y un gran número de corales que se asentaron sobre los corales muertos y crecieron. En general, las superficies del esqueleto de 12 especies de corales fueron colonizadas por 16 especies de corales, con un máximo de 12 colonizadores en cada colonia, la mayoría (67\%) sobre esqueletos de Montastraea annularis (complejo). Colonias completamente muertas de $M$. annularis fueron comunes y los sobrevivientes con frecuencia son más pequeños o subdivididos en pequeños restos de tejido. Montastraea annularis es la especie que exhibe una mayor mortalidad parcial en relación con los demás corales. Una notable ausencia de reclutamiento sexual y juveniles de $M$. annularis ilustra el cambio progresivo de cambio de un sistema dominado por Montastraea. Este cambio, que se está produciendo en todo el Caribe, se caracteriza por un dominio cada vez mayor de especies más pequeñas y de vida corta como Agaricia y Porites, y una reducción en el tamaño de los corales masivos longevos. El seguimiento de la sobrevivencia de los reclutas es necesario para determinar si los arrecifes del Caribe mantendrán la misma función, estructura, identidad y retroalimentación (signos clave de la resiliencia), y si las pérdidas de $M$. annularis (complejo) continuarán a los niveles actuales. La evaluación rápida presentada aquí posibilita caracterizar la estructura de tamaño de las colonias, los niveles de reclutamiento y determinar si los corales pequeños representan sobrevivientes de colonias que incrementan su tamaño o colonias grandes (más viejas) que siguen disminuyendo de tamaño. Este enfoque puede ayudar a determinar la historia de un sitio y su capacidad de recuperación.

Palabras clave: resiliencia, estructura en la talla del coral, reclutamiento de coral, sobrevivencia y crecimiento, monitoreo de corales, evaluación de corales

\section{REFERENCES}

Almany, G.R., M.L. Berumen, S.R. Thorrold, S. Planes \& G.P. Jones. 2007. Local replenishment of coral reef fish populations in a marine reserve. Science 316: 742-744.

Almany, G.R., S.R. Connolly, D.D. Heath, J.D. Hogan, G.P. Jones, L.J. McCook, M. Mills, R.L. Pressey, \& D.H. Williamson. 2009. Connectivity, biodiversity conservation, and the design of marine reserve networks for coral reefs. Coral Reefs 28: 339-351.

Aronson, R.B. \& W.F. Precht. 2001. White-band disease and the changing face of Caribbean coral reefs. Hydrobiologia 460: 25-38.

Aronson, R.B., I.G.MacIntyre, W.F. Precht, T.J.T. Murdoch \& C.M. Wapnick. 2002. The expanding scale of species turnover events on coral reefs in Belize. Ecol. Monogr. 72: 233-249.

Babcock, R.C. 1991. Comparative demography of three species of scleractinian corals using age- and sizedependent classifications. Ecol. Monogr. 61:225-244.

Babcock, R. \& C. Mundy.1996. Coral recruitment: consequences of settlement choice for early growth and survivorship in two scleractinians. J. Exp. Mar. Biol. Ecol. 206: 179-201.

Bak, R.P.M. \& E.H. Meesters. 1998. Coral population structure: the hidden information of colony sizefrequency distributions. Mar. Ecol. Prog. Ser. 162: 301-306.

Bak, R.P.M. \& E.H. Meesters. 1999. Population structure as a response of coral communities to global change. Am. Zool. 39: 56-65.

Ballantine, D.L., R.S. Appeldoorn, P. Yoshioka, E. Weil, R. Armstrong, J.R. Garcia, E. Otero, F. Pagan, C. Sherman, E.A. Hernandez-Delgado, A. Bruckner \& C. Lilyestrom. 2008. Biology and ecology of Puerto 
Rican Coral Reefs. p. 375-406. In B.M. Reigl \& R.E. Dodge (eds.) Coral Reefs of the World 1: Coral Reefs of the USA. Springer, Berlin, Germany.

Bellwood, D.R., T.P. Hughes, C. Folke \& M. Nyström. 2004. Confronting the coral reef crisis. Nature 429: 827-833.

Bruckner, A.W. 2003. Proceedings of the Caribbean Acropora workshop: potential application of the Endangered Species Act as a conservation strategy. NOAA Technical Memorandum NMFS-OPR-24, Silver Spring, Maryland.

Bruckner, A.W. \& R.J. Bruckner. 2003. Condition of coral reefs off less developed coastlines of Curaçao (stony corals and algae). Atoll Res. Bull. 496: 370-393.

Bruckner, A.W. \& R.J. Bruckner. 2006a. Consequences of yellow band disease (YBD) on Montastraea annularis (species complex) populations on remote reefs off Mona Island, Puerto Rico. Dis. Aquatic Org. 69: 67-73.

Bruckner, A.W. \& R.J. Bruckner. 2006b.The recent decline of Montastraea annularis (complex) coral populations in western Curacao: a cause for concern? Rev. Biol. Trop. 54 (Suppl. 1): 45-58.

Bruckner, A.W. \& R. Hill. 2009. Ten years of change to coral communities off Mona and Desecheo Islands, Puerto Rico from disease and bleaching. Dis. Aquatic Org. 87: 19-31.

Bruno, J.F. \& E.R. Selig. 2007. Regional Decline of Coral Cover in the Indo-Pacific: Timing, Extent, and Subregional Comparisons. PLoS ONE 2(8): e711. doi:10.1371/journal.pone.0000711

Bruno, J.F., E.R. Selig, K.S. Casey, C.A. Page, B.L.Willis, C.D. Harvell, H. Sweatman \& A.M. Melendy. 2007. Thermal stress and coral cover as drivers of coral disease outbreaks. PLoS Biol. 5(6): e124.

Carpenter, R.C. 1990. Mass mortality of Diadema antillarum. I. Long- term effects on sea urchin populationdynamics and coral reef algal communities. Mar. Biol. 104: 67-77.

Carpenter, R.C. \& P.J. Edmunds. 2006. Local and regional scale recovery of Diadema promotes recruitment of scleractinian corals. Ecol. Lett. 9: 271-80.

Cowen, R.K., C.B. Paris \& A. Srinivasan. 2006 Scaling of connectivity in marine populations Science 311 : 522-527.

Edmunds, P.J. \& R.C. Carpenter. 2001. Recovery of Diadema antillarum reduces macroalgal cover and increases the abundance of juvenile corals on a Caribbean reef. Proc. Nat. Acad. Sci. USA 98: 5067-5071.

Edmunds, P.J. \& R. Elahi. 2007. The demographics of a 15-year decline in cover of the Caribbean reef coral Montastraea annularis. Ecol. Monogr. 77: 3-18.

Folke, C., C.S. Holling, \& C. Perrings 1996. Biological diversity, ecosystems, and the human scale. Ecol. Appl. 4: 1018-1024.

Gardner, T.A., I.M. Cote, F.A. Gill, A. Grant \& A.R. Watkinson. 2003. Long-term region-wide declines in Caribbean corals. Science 301: 958-960.

Green, A.L. \& D.R. Bellwood. 2009. Monitoring functional groups of herbivorous reef fishes as indicators of coral reef resilience - A practical guide for coral reef managers in the Asia Pacific region. IUCN working group on Climate Change and Coral Reefs. IUCN, Gland, Switzerland. 70 pages.

Grimsditch, G.D. \& R.V. Salm. 2006. Coral reef resilience and resistance to bleaching. IUCN, Gland, Switzerland. $52 \mathrm{p}$.

Hall, V.R. \& T.P. Hughes 1996. Reproductive strategies of modular organisms: comparative studies of reef building corals. Ecology 77: 950-963.

Harrison, P.L.\& C.C. Wallace. 1990. Reproduction, dispersal and recruitment of scleractinian corals, p. 133-207 In Z. Dubinsky (ed.) Ecosystems of the world: coral reefs. Elsevier, Amsterdam, Holland.

Holling, C.S. 1973. Resilience and stability of ecological systems. Ann. Rev. Ecol. System. 4:1-23.

Hughes, T.P. 1994. Catastrophes, phase shifts, and largescale degradation of a Caribbean coral reef. Science 265: 1547-1551.

Hughes. T.P. \& J.B.C. Jackson. 1985. Population dynamics and life histories of foliaceous coral. Ecol. Monogr. 55: 141-166.

Hughes, T.P., A.H. Baird, D.R. Bellwood, M. Card, S.R. Connolly, C. Folke, R. Grosberg, O. Hoegh-Guldberg, J.B.C. Jackson \& J. Kleypas. 2003. Climate change, human impacts, and the resilience of coral reefs. Science 301: 929-933.

Hughes, T.P., D.R. Bellwood, C. Folke, R.S. Steneck \& J. Wilson. 2005. New paradigms for supporting the resilience of marine ecosystems. Trends Ecol. Evol. 20: 380-386. 
Hughes, T.P., M.J. Rodrigues, D.R. Bellwood, D. Ceccarelli, O. Hoegh-Guldberg, L. McCook, N. Moltschaniwskyj, M.S. Pratchett, R.S. Steneck \& B. Willis. 2007. Phase shifts, herbivory, and the resilience of coral ceefs to climate change. Current Biol. 17: 360-365.

Jackson, J.B.C., M.X. Kirby, W.H. Berger, K.A. Bjorndal, L.W. Botsford, B.J. Bourque,C.H. Peterson, R.S Steneck, M.J. Tegner \& R.B. Warner. 2001. Historical overfishing and the recent collapse of coastal ecosystems. Science 293: 629-638.

Jennings, S. \& M.J. Kaiser. 1998. The effects of fishing on marine ecosystems. Adv. Mar. Biol. 34: 201-352.

Jones, G.P., G.R. Almany, G.D. Russ, P.F. Sale, R.S. Steneck, M.J.H. van Oppen \& B.L. Willis. 2009. Larval retention and connectivity among populations of corals and reef fishes: history, advances and challenges. Coral Reefs 28: 307-325., N. \& J.B.C. . Shifting baselines, local impacts, and global change on coral reefs. PLoS Biology 6: e54, 6.

Lang, J.L. 2003. Status of coral reefs in the western Altantic: results of initial surveys, Atlantic and Gulf Rapid Reef Assessment (AGGRA) program. Atoll Res. Bull. 496, 630 p.

Lang, J., K.W. Marks, P.A. Kramer, P.R. Kramer \& R.N. Ginsburg. 2010. AGRRA Protocols Version 5.4. online at http://www.agrra.org/method/methodhome.html

Lessios, H.A. 1988. Mass mortality of Diadema antillarum in the Caribbean: What have we learned? Ann. Rev. Ecol. Syst. 19: 371-393.

McClanahan, T.R., M.J. Marnane, J.E. Cinner \& W.E. Kiene. 2006. A comparison of marine protected areas and alternative approaches to coral-reef management. Curr. Biol. 16: 1408-1413.

McClanahan, T.R., N.A.J. Graham, M. A. MacNeil, N.A Muthiga, J.E. Cinner, J. Henrich Bruggemann \& S.K. Wilson. 2011. Critical thresholds and tangible targets for ecosystem-based management of coral reef fisheries. Proc. Natl. Acad. Sci. USA 108: 17230-17233

Meesters, E.H., M. Noordeloos \& R.P.M. Bak. 1994. Damage and regeneration: links to growth in the reefbuilding coral Montastrea annularis. Mar. Ecol. Prog. Ser. 112:119-128.

Muller, E., C. Rogers, A. Spitzack \& R. van Woesik. 2008. Bleaching increases likelihood of disease on Acropora palmata (Lamarck) in Hawksnest Bay, St John, US Virgin Islands. Coral Reefs 27: 191-195.
Mumby, P.J. 2006. The impact of exploiting grazers (Scaridae) on the dynamics of Caribbean coral reefs. Ecol Appl. 16: 747-69.

Mumby, P.J., C.P. Dahlgren, A.R. Harborne, C.V. Kappel, F. Micheli, D.R. Brumbaugh, K.E. Holmes, J.M. Mendes, K. Broad, J.N. Sanchirico, K. Buch, S. Box, R.W. Stoffle \& A.B. Gill, 2006. Fishing, trophic cascades, and the process of grazing on coral reefs. Science 311: 98-101.

Mumby, P.J. \& A.R. Harborne. 2010. Marine reserves enhance the recovery of corals on Caribbean reefs. PloS One 5(1): e8657. doi:10.1371/journal. pone. 0008657

Norström, A.V., M. Nyström, J. Lokrantz \& C. Folke. 2009. Alternative states on coral reefs: beyond coralmacroalgal phase shifts. Mar. Ecol. Prog. Ser. 376: 295-306.

Nyström, M. \& C. Folke. 2001. Spatial resilience of coral reefs. Ecosystems. 4: 406-417.

Nyström, M., N.A.J. Graham, J., Lokrantz \& A. Norström. 2008. Capturing the cornerstones of coral reef resilience: linking theory to practice. Coral Reefs 27 : 795-809.

Obura, D.O. \& G. Grimsdith (eds.). 2009. Resilience Assessment of coral reefs - Assessment protocol for coral reefs, focusing on coral bleaching and thermal stress. IUCN working group on Climate Change and Coral Reefs. IUCN, Gland, Switzerland. 70 p.

Raymundo, L.J., C.S. Couch, A.W. Bruckner, C.D. Harvell, T.M. Work, E.Weil, C.M. Woodley, E. JordanDahlgren, B.L. Willis, G.S. Aeby \& Y. Sato. 2008. Coral Disease Handbook: Guidelines for Assessment, Monitoring and Management. CRTR, Australia. $131 \mathrm{p}$.

Roberts, C.M. 1997. Connectivity and management of Caribbean coral reefs. Science 278: 1454-1457.

Roberts, C.M., J.A. Bohnsack, F. Gell, J.P. Hawkins, and R. Goodridge, 2001. Effects of marine reserves on adjacent fisheries. Science 294: 1920-1923.

Rogers, C.S., J. Miller, E. Muller, P. Edmunds, R.S. Nemeth, J.P. Beets, A.M. Friedlander, T.B. Smith, R. Boulon, C.F.G. Jeffrey, C. Menza, C. Caldow, N. Idrisi, B. Kojis, M.E. Monaco, A. Spitzack, E.H. Gladfelter, J.C. Ogden, Z. Hillis-Starr, I. Lundgren, W.B. Schill, I.B. Kuffner, L.L. Richardson, B.E. Devine \& J.D. Voss. 2008. Ecology of coral reefs in the US Virgin Islands, p. 303-374. In B. Riegl \& R. E. Dodge (eds.) Coral Reefs of the World. 1. Coral Reefs of the USA. Springer, Berlin, Germany. 
Soong, K. 1991. Sexual reproductive patterns of shallowwater reef corals in Panama. Bull. Mar. Sci. 49: 832-846.

Soong, K. \& J.C. Lang. 1992. Reproductive integration in reef corals. Biol. Bull. 183: 418-431.

Szmant-Froelich, A.M. 1985. The effect of colony size on the reproductive ability of the Caribbean coral Montastrea annularis (Ellis and Solander). Proc. 5th Int. Coral Reef Congress, Tahiti 4: 295-300.

Szmant, A.M. 1991. Sexual reproduction by the Caribbean reef corals Montastrea annularis and M. cavernosa. Mar. Ecol. Prog. Ser. 74: 13-25.
Sutherland, K., J. Porter \& C. Torres. 2004. Disease and immunity in Caribbean and Indo-

Pacific zooxanthellate corals. Mar. Ecol. Prog. Ser. 266: 273-302.

Weil, E. 2004. Coral reef diseases in the wider Caribbean, p. 35-68. In E. Rosenberg \& Y. Loya (eds.) Coral Health and Disease. Springer-Verlag, Berlin, Germany.

Worm, B., E.B. Barbier, N. Beaumont, J. E Duffy, C. Folke, B.S. Halpern, J.B.C. Jackson, H.K. Lotze, F. Micheli, S.R. Palumbi, E. Sala, K.A. Selkoe, J.J. Stachowicz \& R. Watson. 2006. Impacts of biodiversity loss on ocean ecosystem services. Science 314: 787-790. 
